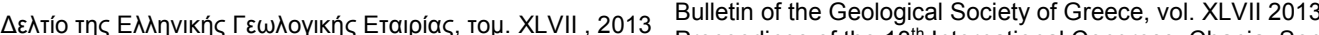
Proceedings of the $13^{\text {th }}$ International Congress, Chania, Sept.

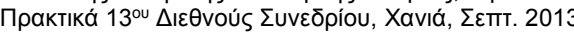
2013

\title{
MULTI-STAGE HISTORY OF COMPOUND MANTLE XENOLITHS FROM WESTERN USA: IMPLICATIONS FOR METASOMATIC PROCESSES IN THE DEEP MANTLE
}

\author{
Baziotis I. ${ }^{1,2}$, Asimow P.D. ${ }^{3}$, Koroneos A. ${ }^{1}$, Poli G. ${ }^{2}$ and Ntaflos T. ${ }^{4}$ \\ ${ }^{1}$ Department of Mineralogy, Petrology and Economic Geology, Aristotle University of \\ Thessaloniki, 54124, Thessaloniki, Greece, ibaziotis@geo.auth.gr \\ ${ }^{2}$ Department of Earth Sciences, University of Perugia, 06100, Perugia, Italy \\ ${ }^{3}$ California Institute of Technology, Division of Geological and Planetary Sciences, Pasadena, \\ California, USA \\ ${ }^{4}$ Department of Lithospheric Research, University of Vienna, 1090, Vienna, Austria
}

\begin{abstract}
The compound mantle xenoliths from Cima Volcanic Field and Chino Valley (Western U.S.A.) represent outstanding candidates to illustrate the processes that occur prior to their delivery to the surface by alkali-basaltic volcanism. The xenoliths share characteristics like pyroxene zonation, amphibole breakdown and formation of glass and armalcolite. Their petrogenetic evolution involved partial melting of the silicate minerals, infiltration of reactive melts and dissociation of minerals en route to the surface, suggesting that these rocks followed multi-stage histories that initiated deep in the mantle (>1.0 GPa) and proceeded during a very short period of time. Key words: lherzolite; partial melting; mantle metasomatism.
\end{abstract}

\section{Пєрí $\eta \psi \eta$}

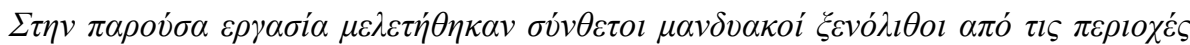

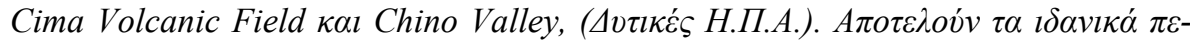

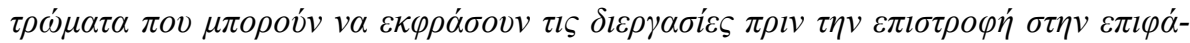

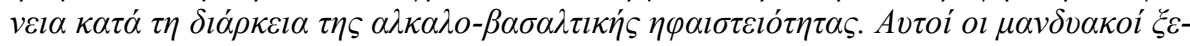

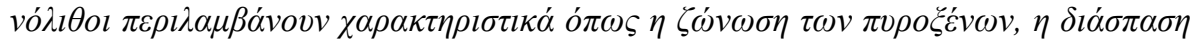

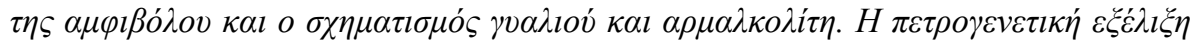

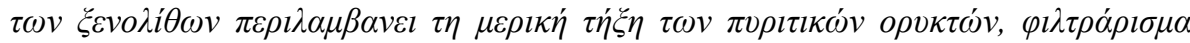

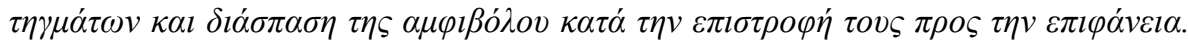

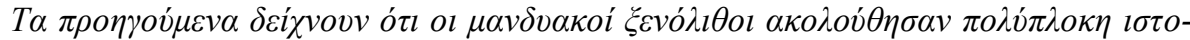

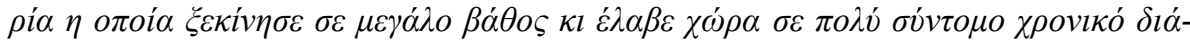
$\sigma \tau \eta \mu \alpha$.

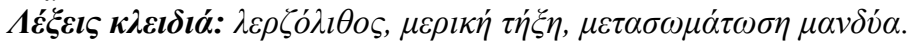

\section{Introduction}

The mantle is the major geochemical reservoir of most rock-forming elements in the Earth. Convection and plate-tectonic driven processes act to generate local and regional heterogeneity 
within the mantle, which in turn through thermal and chemical interactions modulates ongoing geophysical processes; this feedback shapes the dynamics of the deep interior. Consequently, these processes contribute to the evolution of the Earth throughout its geological history.

Up to now, the heterogeneity of the mantle has been extensively studied in terms of conventional methods using basalt chemistry, bulk rock analysis of isolated xenolith specimens of varying lithology, and massif exposures. In the current study we focus on multi-layered xenoliths. In particular we choose lherzolites with amphibole-rich veins and lherzolites with websterite/clinopyroxenite contacts. The mineral assemblages of such layers carry information about partial melting and mantle metasomatism. Our major goal is to identify the signatures that were recorded during the ascent of these mantle xenoliths toward the surface in their alkali basalt host liquids. After that, we hope be able to unravel the principal processes that, earlier in the evolution of these samples, controlled the formation of the different layers of the mantle xenoliths.

\section{Sampling Areas - Description}

\subsection{Geological Setting}

For the purpose of the current study we used selected compound xenoliths from Cima Volcanic Field and Chino Valley (Fig. 1). The Cima Volcanic Field represents an isolated late Cenozoic basaltic field, part of the southern Basin and Range province, and is located in the Mojave Desert, southeastern California, USA. Chino Valley is in central Arizona, just off the southwestern edge of the Colorado Plateau occur within the Transition Zone which has a variable width (60 to $100 \mathrm{~km}$ ). The tectonic framework of the area is characterized by extension of the Basin and Range crust related with Cordilleran metamorphic core complexes and synchronous felsic volcanism. The volcanic fields in Arizona share five petrologic types: a) lamprophyres, b) latites, c) basaltdominated fields, d) basalt-rhyolite fields and andesite-rhyolite-dominated fields (Nealey and Sheridan, 1989).

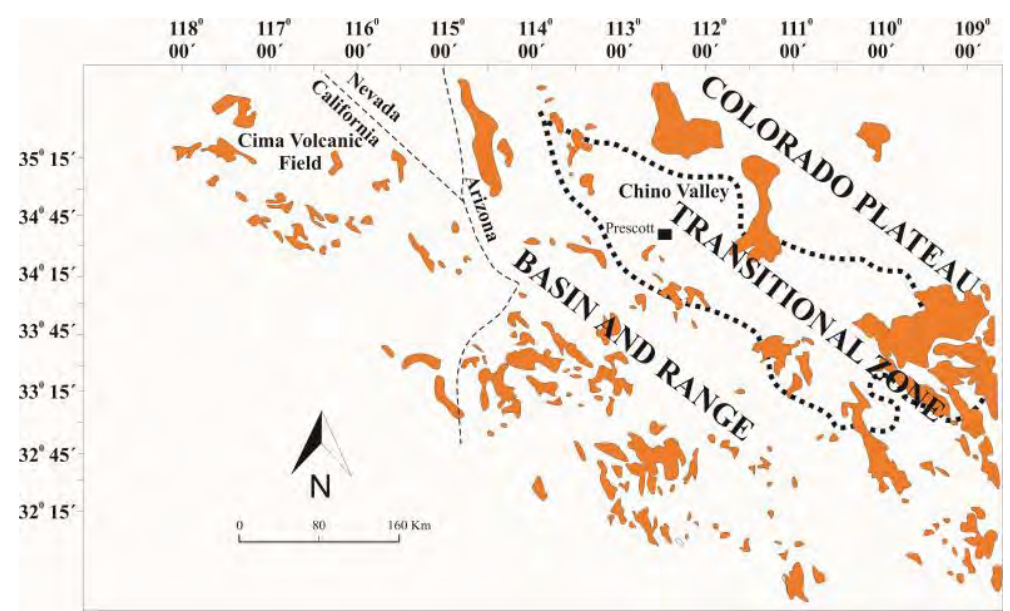

Figure 1 - Simplified map showing the locations of Cenozoic volcanics (in orange) that host the mantle xenoliths used in this study (Cima Volcanic Field and Chino Valley). (Map modified after Reynolds, 1988 and Farmer et al., 1995).

\subsection{Mantle Xenoliths}

The composite xenoliths occur within Cenozoic volcanics rocks. The Cima Volcanic Field, provides samples with contacts among different lithologies. Such diverse lithologies represented by $\mathrm{Cr}$-diopside spinel peridotite, websterite, gabbro, clinopyroxenite and wehrlite, commonly occur in alkali basaltic lavas (Irving, 1980; Wilshire et al., 1991). The Chino Valley xenoliths include lithologies like garnet websterites, phlogopite-bearing websterite and garnet-amphibole 
rocks but the predominant type is garnet clinopyroxenite (Schulze et al., 1978; Wilshire et al., 1991). All the samples are from the Howard Wilshire collection archived at the Smithsonian Institution, Washington DC, USA. The criteria for the selection of these compound xenoliths were freshness and integrity of specimens, maximum distance on both sides of lithologic contacts, and rock types thought most likely to represent subsolidus juxtaposition of different lithologies that later partially melted in contact.

\section{Analytical Methods}

Major element compositions of minerals were determined in polished thin sections using a CAMECA SX 100 electron microprobe equipped with four wavelength-dispersive spectrometers (WDS) and one energy-dispersive spectrometer (EDS) at the University of Vienna, Department of Lithospheric Research (Austria). Operating conditions were accelerating voltage $15 \mathrm{kV}$. For minerals, a $20 \mathrm{nA}$ beam current and $20 \mathrm{~s}$ counting time on peak position were used. For glass analyses, a slightly defocused beam with $5 \mu \mathrm{m}$ diameter and $10 \mathrm{~s}$ counting time were used. Natural mineral used as standards as follows: albite $(\mathrm{Na}, \mathrm{Si}, \mathrm{Al})$, wollastonite $(\mathrm{Ca})$, olivine $(\mathrm{Mg})$, almandine $(\mathrm{Fe})$, spessartine $(\mathrm{Mn})$, orthoclase $(\mathrm{K})$, rutile $(\mathrm{Ti})$, chromite $(\mathrm{Cr})$ and Ni-oxide $(\mathrm{Ni})$. Representative mineral compositions are given in Table 1.

Table 1- Representative mineral compositions from the studied mantle xenoliths.

\begin{tabular}{|c|c|c|c|c|c|c|c|c|c|c|c|c|}
\hline \multicolumn{2}{|c|}{ Sample } & \multicolumn{8}{|c|}{ Ci-1-254 } & \multicolumn{3}{|c|}{ Ci-1-546 } \\
\hline Mineral & $\mathrm{Ol}^{\mathrm{c}}$ & $\mathrm{OI}^{\mathrm{r}}$ & $\begin{array}{c}\text { Cpx- } \\
1\end{array}$ & $\begin{array}{c}\text { Cpx- } \\
2\end{array}$ & Opx & Amp & $\begin{array}{c}\text { Spl- } \\
1\end{array}$ & $\begin{array}{c}\text { Spl- } \\
2\end{array}$ & PI & Gl-1 & GI-2 & Arm \\
\hline $\mathrm{SiO}_{2}$ & 40.5 & 40.7 & 52.0 & 47.0 & 55.3 & 42.1 & 0.06 & 0.06 & 56.3 & 59.1 & 56.7 & 0.14 \\
\hline $\mathrm{TiO}_{2}$ & - & - & 0.31 & 2.21 & 0.09 & 2.12 & 0.11 & 0.73 & 0.29 & 3.09 & 2.73 & 72.3 \\
\hline $\mathrm{Al}_{2} \mathrm{O}_{3}$ & 0.04 & 0.73 & 5.05 & 8.87 & 3.75 & 14.8 & 55.1 & 49.1 & 26.7 & 17.3 & 18.5 & 1.84 \\
\hline $\mathrm{Cr}_{2} \mathrm{O}_{3}$ & - & 0.05 & 0.67 & 1.23 & 0.35 & 1.29 & 12.4 & 16.8 & - & 0.01 & 0.02 & 2.68 \\
\hline $\mathrm{NiO}$ & 0.43 & 0.31 & 0.08 & 0.07 & 0.13 & - & 0.41 & 0.39 & - & - & - & - \\
\hline $\mathrm{FeO}$ & 10.1 & 9.57 & 3.02 & 2.75 & 6.59 & 4.20 & 11.5 & 12.7 & 0.42 & 2.70 & 3.72 & 9.71 \\
\hline $\mathrm{MnO}$ & 0.14 & 0.15 & 0.08 & 0.04 & 0.15 & 0.06 & 0.08 & 0.12 & 0.01 & 0.04 & 0.04 & 0.04 \\
\hline $\mathrm{MgO}$ & 48.6 & 47.9 & 16.2 & 14.2 & 33.0 & 16.9 & 20.6 & 19.9 & 0.17 & 2.68 & 4.00 & 12.1 \\
\hline $\mathrm{CaO}$ & 0.08 & 0.25 & 21.9 & 22.9 & 0.84 & 11.5 & 0.03 & 0.04 & 9.61 & 3.92 & 7.94 & 0.16 \\
\hline $\mathrm{Na}_{2} \mathrm{O}$ & - & - & 0.76 & 0.46 & 0.04 & 2.81 & - & - & 5.50 & 3.64 & 3.84 & - \\
\hline $\mathrm{K}_{2} \mathrm{O}$ & - & - & - & - & 0.01 & 1.17 & - & - & 0.53 & 4.43 & 1.31 & 0.11 \\
\hline $\mathrm{ZnO}$ & - & - & - & - & - & - & 0.12 & 0.09 & - & - & - & - \\
\hline Total & 99.9 & 99.7 & 100.1 & 99.7 & 100.3 & 96.9 & 100.3 & 99.9 & 99.5 & 97.0 & 98.9 & 99.1 \\
\hline
\end{tabular}

\section{Petrography}

\subsection{Cima Volcanic Field}

\subsubsection{Sample Ci-1-254}

Mantle xenolith is in contact with the host basalt. The compound xenolith consists of two predominant layers: websterite and lherzolite, characterized as coarse-grained and porphyroclastic, respectively (Mercier and Nicolas, 1975). Discrete veins penetrate the lherzolite layer, probably originated from the host basalt. On the other hand, the websterite shows recrystallization features 
at the contact with the host basalt (Fig. 2a). The lherzolite is amphibole-bearing; infiltrated melts crystallized Ti-rich pargasite (Table 1) showing no reaction relation with peridotite minerals (see Wilshire et al., 1991). However, the amphibole is decomposed, probably due to rapid decompression melting en route to the surface. Olivine grain size in the lherzolites is smaller than orthopyroxene grain size in the websterite layer.

\subsubsection{Sample Ci-1-546:}

Mantle xenolith is in contact with the host basalt (Fig. 2b). The compound xenolith consists of alternating layers of porphyroclastic clinopyroxenite (2 layers), coarse-grained lherzolite (4 layers) and orthopyroxenite (1 layer). The majority of the amphiboles are located within lherzolite (near the host basalt) and the adjacent clinopyroxenite layer. Lherzolites host large olivine crystals whereas the clinopyroxenite contains small crystals with a well-developed preferred orientation.

\subsection{Chino Valley}

\subsubsection{Sample PN-1-14:}

Mantle xenolith with a distinct crude central cumulate-like layer characterized by coarse dark clinopyroxene ( $>85$ vol. \%) with a size $>0.5 \mathrm{~mm}$ (Fig. 2c). Clinopyroxene exhibits a spongy texture, enclosing and surrounded by tiny Fe-Ti oxides. Fe-Ca-Ti oxides (mainly ilmenite and titanite) were observed as discrete grains in the matrix as well. The clinopyroxene-ilmenite assemblage shows a moderately-developed preferred orientation. The contact is clear, although gradational (decreasing grain size), on both sides of the clinopyroxene-rich layer.

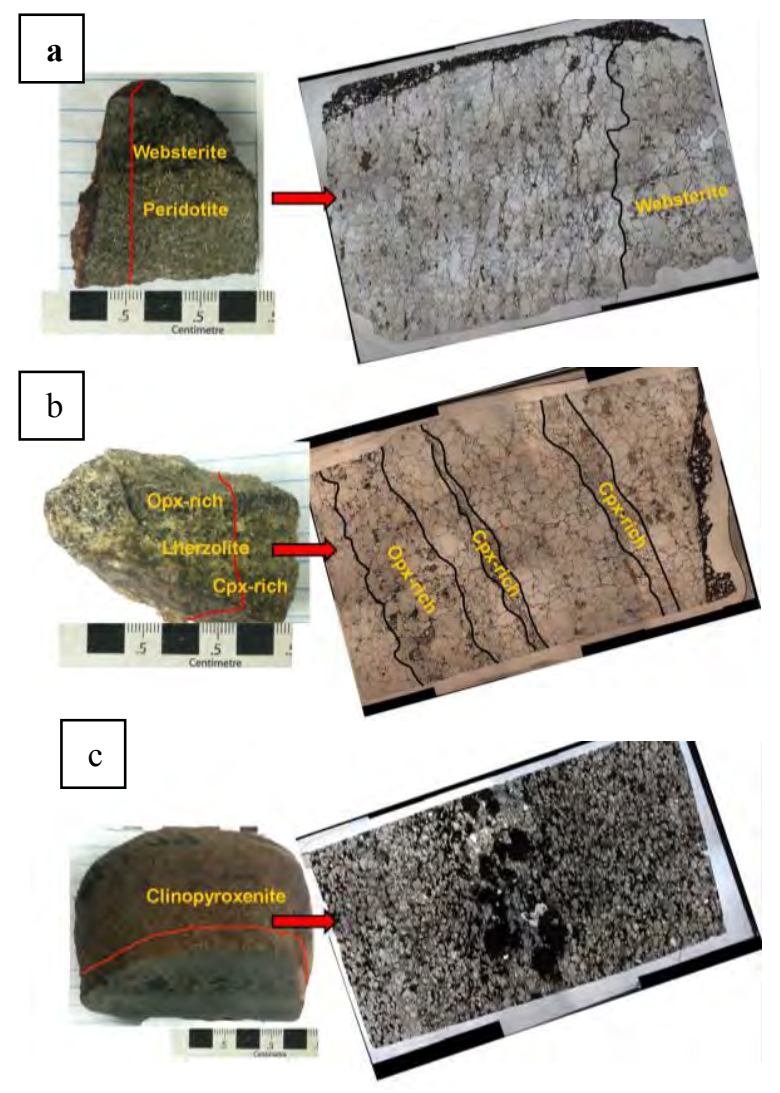

Figure 2 - Images of samples a) Ci-1-254, b) Ci-1-546 from Cima Volcanic Field and c) Pn-114 from Chino Valley. a,b) xenoliths with a multi-layered structure and c) cumulate rock with abundant clinopyroxene and widespread ilmenite-rutile grains.

XLVII. No $1-360$ 


\section{Results and Discussion}

In a websterite layer from the composite xenolith Ci-1-254 of Cima Volcanic Field, primary clinopyroxene is overgrown by secondary one. Secondary clinopyroxene is enriched in $\mathrm{Al}_{2} \mathrm{O}_{3}$, $\mathrm{CaO}, \mathrm{Cr}_{2} \mathrm{O}_{3}$ and $\mathrm{TiO}_{2}$, and depleted in $\mathrm{SiO}_{2}, \mathrm{Na}_{2} \mathrm{O}, \mathrm{FeO}$ and $\mathrm{MgO}$ compared to the primary clinopyroxene (Table 1). The adjacent amphibole corresponds to a Ti-rich pargasite (Table 1). Between secondary clinopyroxene and amphibole, a $30 \mu \mathrm{m}$ wide zone occurs with neo-formation of orthopyroxene, spinel (Spl-2), olivine (Ol-2), glass and armalcolite (Fig. 3). The presence of secondary clinopyroxene along with the reaction zone probably signifies two contemporaneous events. The first event is characterized by penetration of $\mathrm{Ca}$ and Ti-rich melt (inferred from glass-1 composition; see Table 1) and the second is associated with the decomposition of the amphibole. During the same event, the primary clinopyroxene $(\mathrm{Cpx}-1)$ reacts with the infiltrated melt forming the secondary clinopyroxene $(\mathrm{Cpx}-2)$. Alternatively, the second clinopyroxene elemental inhomogeneity could be related with rapid crystallization. This process displaces the system toward more calcic-aluminous-titaniferous compositions. At the same time, the amphibole breakdown is facilitated by the presence of the remnant melt (Fig. 3a). The breakdown zone occurs nearly at the same time with the clinopyroxene suggested by the inclusions of spinel (Spl-2) and glass at the rim of the Cpx-2 (Fig. 3c). These phenomena occur during decompression, and at relative fast rates, otherwise crystallization at depth would prefer the formation of larger crystals and absence of glass.
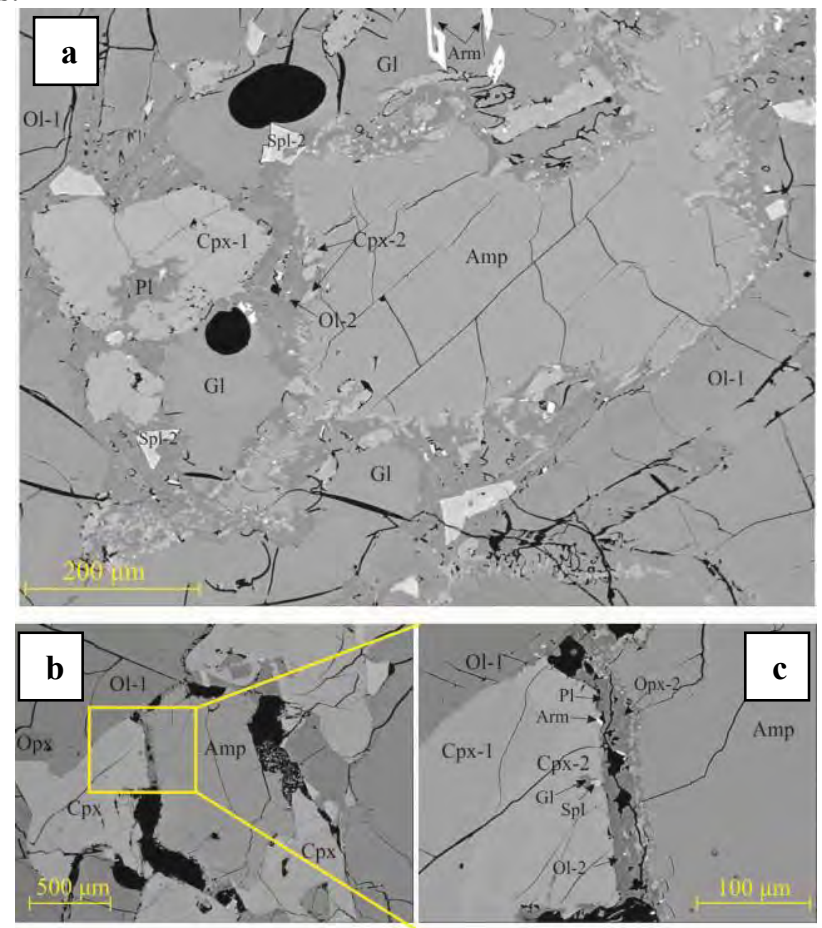

Figure 3 - a) Amphibole surrounded by small idiomorphic clinopyroxene (Cpx-2), olivine (Ol-2) and spinel (Spl-2) crystals and plagioclase in a matrix composed by olivine (Ol-1) and clinopyroxene (Cpx-1). Glass occurs as interstitial patches developed at the expense of amphibole. It is characterized by the presence of armalcolite as well, b, c) amphibole (Amp), clinopyroxene and olivine (Ol-1) in contact within a websterite layer. Ca-Tschermak rich clinopyroxene (Cpx-2) overgrown on diopside-rich (Cpx-1), c) decomposition of amphibole showing a $30 \mu \mathrm{m}$ wide zone composed by clinopyroxene (Cpx-2), olivine (Ol-2), orthopyroxene (Opx-2) and plagioclase ( $\mathrm{Pl})$. Glass and small quench spinel (Spl) crystal are enclosed at the Cpx-2, probably during the simultaneous processes of amphibole breakdown and infiltration of a melt. a-c: backscatter electron (BSE) images. 
In another composite xenolith (sample Ci-1-546) from the Cima Volcanic Field, the amphibolebearing lherzolite has Ti-rich pargasite that is surrounded by glass-1, spinel, plagioclase, clinopyroxene, olivine and armalcolite (Fig. 3a, 4a). The latter is entrained within the glass pocket and has a skeletal crystal shape suggesting rapid growth at high pressures $(>1.0 \mathrm{GPa}$ but most probably at $\sim 1.3 \mathrm{GPa}$ due to $\mathrm{Cr}-\mathrm{Al}$ content; see Friel et al., 1977 and Grègoire et al., 2000) and low oxygen fugacity at mantle depths (e.g., Medvedev, 1996). The presence of glass-1 is associated with rapid melting (e.g., Francis, 1991) and breakdown of pargasite to $\mathrm{Ol}+\mathrm{Cpx}+\mathrm{Spl}+\mathrm{Gl}-1)$ en route to the surface. Isolate ${ }^{1}$ glass- 2 is observed, interstitially along grain boundaries of pyroxenes and olivine; it is depletec in $\mathrm{Si}, \mathrm{Ti}, \mathrm{K}$ and enriched in $\mathrm{Ca}, \mathrm{Mg}, \mathrm{Al}$ compared to glass-1 (Fig. 4; Table 1).
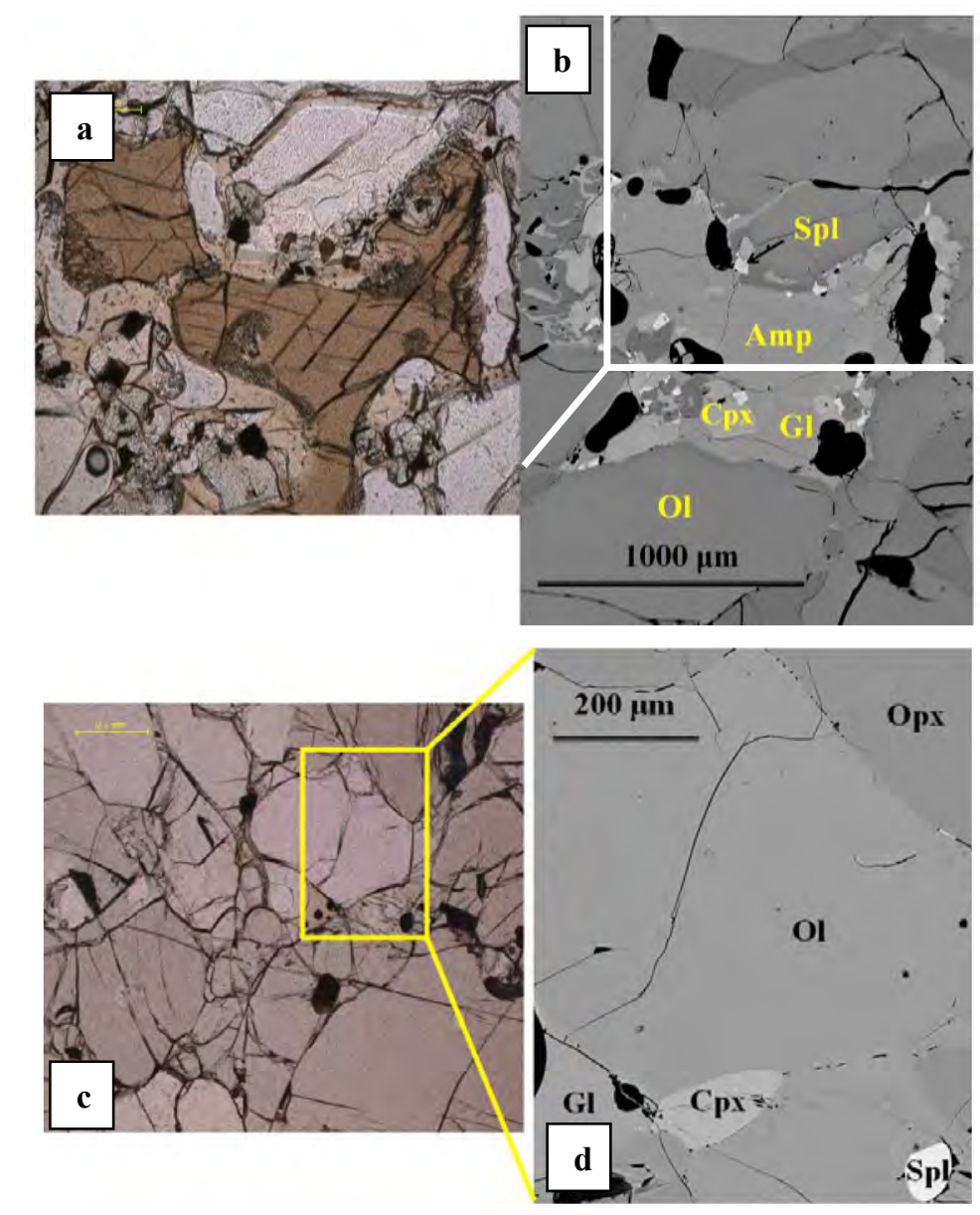

Figure 4 - a, b) Amphibole (Amp) surrounded by small idiomorphic spinels (Spl), clinopyroxene (Cpx) and glass (GI). Note empty cavities associated with volatile escape. The presence of glass surrounding amphibole suggests rapid decompression melting of the amphibole en route to the surface and $\mathrm{c}, \mathrm{d}$ ) formation of glass interstitial between olivine $\mathrm{OI}$ ), clinopyroxene (Cpx) and orthopyroxene (Opx). Orthopyroxene contain brown idiomorphic spinel inclusions. a, c: photomicrographs PPL; b, d: BSE images.

Fe-Ti minerals identified in the selected xenoliths include armalcolite and ilmenite (Fig. 5). In the Chino Valley clinopyroxenite (Pn-1-14), Nb-rich and $\mathrm{Nb}$-free rutile both occur as inclusions in titanite (Fig. 5a, b). Commonly rutile is replaced by ilmenite and less commonly by armalcolite (Fig. 5a, b, d). Thus textural relationships suggest that rutile may represent a primary mineral in 

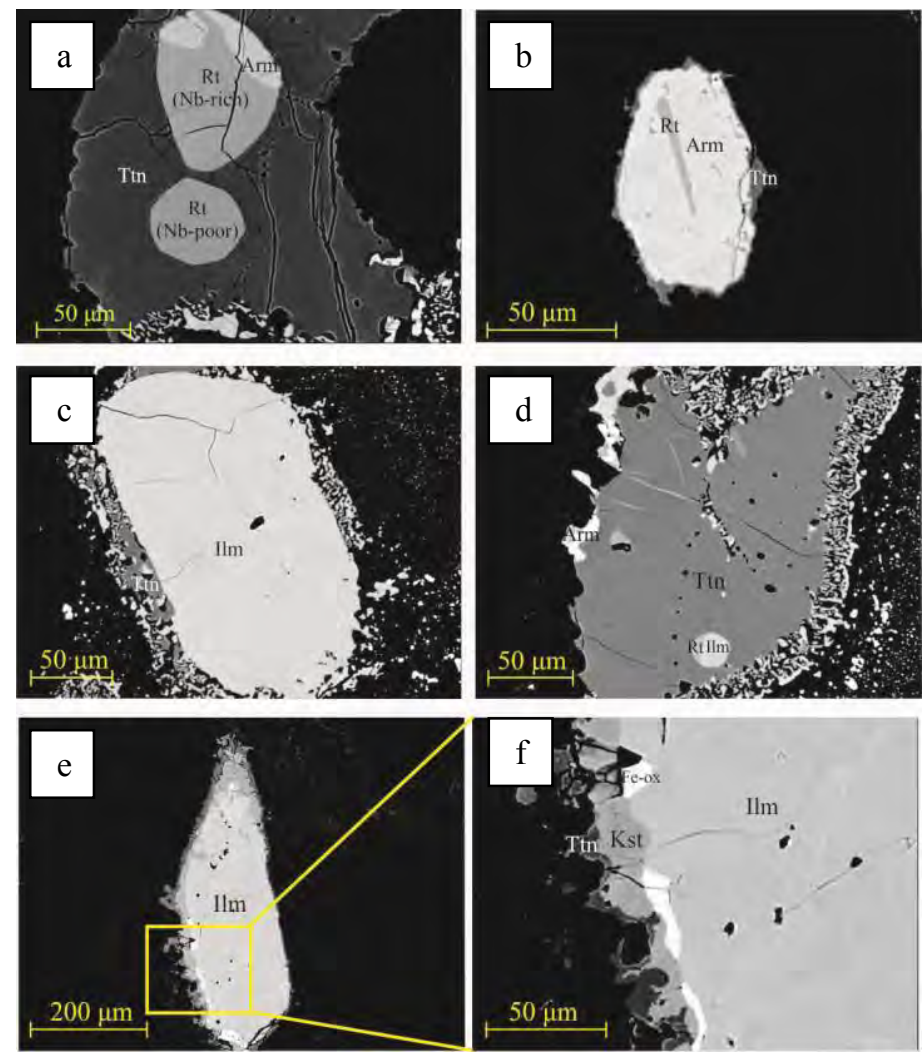

Figure 5 - a) Two rutile (Rt) grains (Nb-rich and Nb-free) occur as inclusions in titanite (Ttn). Nb-rich rutile is partly replaced by armalcolite (Arm), b) rutile lamellae within armalcolite; the latter is being replaced by titanite, $c, d, e)$ sieved-texture around ilmenite (Ilm; c, e) and titanite (d). Titanite has rounded inclusion composed by rutile and ilmenite with straight contact, f) ilmenite mantled by kassite (Kst; a very rare Ca-Ti hydrous oxide) and $\mathrm{Fe}-0 x i d e(\mathrm{Fe}-\mathrm{Ox})$ and then by titanite. a-f: BSE images.

the Chino Valley clinopyroxenite. Alternatively, rutile could be the product after armalcolite breakdown as previously suggested by Lindsley et al. (1974). Moreover, ilmenite is mantled by Fe-oxide + kassite (a rare hydrous $\mathrm{Ca}-\mathrm{Ti}$ oxide) and then by titanite (Fig. 5f). These mineral assemblages imply a change from $\mathrm{Fe}$-Ti to $\mathrm{Ca}$-rich silicate metasomatic agents percolating through the host rock. Further, such Ti-enriched mineral assemblages, indicated by the specific enrichment in high-field strength elements (HFSE; e.g., $\mathrm{Nb}$ ) have been extensively studied in harzburgitic xenoliths from Kerguelen Islands by Grègoire et al. (2000). The authors suggest that exchange reactions of a parental melt with the peridotite wall-rock are essential steps in the formation of armalcolite.

There has been an increasing scientific interest on the origin and transport of the volatiles in the upper mantle. Though, several amphibole-bearing xenoliths found in alkali-basaltic rocks from worldwide occurrences have been extensively studied (Hawaii, USA, Mason, 1968; Massif central, France, Brown et al., 1980; Engaruka, Tanzania, Dawson and Smith, 1982). On these studies, pargasites and titaniferous pargasites occurring in Cr-diopside represent upper mantle products. Also, study of interstitial glass in amphibole-bearing spinel-wehrlite xenoliths from Foster Crater in Antarctica suggested that it originated elsewhere in the upper mantle and not by in-situ melting (Gamble and Kyle, 1987). Gamble and Kyle (1987) based this conclusion on textural similarities of glass in association with olivine and clinopyroxene micro-phenocrysts and on the liquidus phases of the glasses enclosed by amphibole crystals. Recently, Harvey et al. 
(2012) using major and trace element analyses suggest that interstitial glass from Kilbourne Hole peridotite xenoliths provide clues for a single metasomatic event. Moreover, the presence of submicron grain boundary phases like ilmenite, rutile, armalcolite from the same rocks, suggest another metasomatic event operated at HP conditions. In our study, glasses occur in different textural associations (isolated intergranular to clinopyroxene and olivine or as surrounding products of amphibole) and have large variance in their chemistry, supporting an origin through in-situ melting. External fluids/melts play an important role in enrichment of alkalis (e.g., $\mathrm{K}_{2} \mathrm{O}$; as observed in glass-1) in these mantle rocks. Metasomatic agents that can flux in-situ partial melting include carbonatites, Na-alkali and K-alkali silicate (Coltorti et al., 1999, 2000). Using the Ti, K, $\mathrm{Ca}$ and $\mathrm{Na}$ content of our glasses we infer from the $\mathrm{TiO}_{2}+\mathrm{K}_{2} \mathrm{O}$ vs. $\mathrm{CaO}+\mathrm{Na}_{2} \mathrm{O}$ diagram of Coltorti et al. (2000) that the metasomatizing agents had carbonatitic and Na-alkalic affinities. Finally, our samples suggest extended multi-stage histories involving partial melting to form primary minerals, a period of metasomatic alteration, and a short timescale of decompression upon eruption.

\section{Conclusions}

Mineralogical, textural and compositional characteristics of the assemblages observed within the mantle xenoliths from Cima Volcanic Field and Chino Valley reveal a continuous frame of metasomatic processes. In particular, a switch in metasomatism from Fe-Ti to Ca-rich silicate melt is evidenced by the presence of Fe-Ti oxides (ilmenite, armalcolite) overgrown by Ca-silicate mineral (titanite, kassite) rims. Further, rapidly quenched crystals (e.g., spinel), glass and armalcolite formation indicate a very short-timescale of reactions en route to the surface. The mantle xenoliths infiltrated by alkali-basaltic melts interacted with the peridotite-wall rock increasing the HFSE budget of the minerals (presence of $\mathrm{Nb}$-rich and $\mathrm{Nb}$-poor rutile).

\section{Acknowledgments}

We gratefully acknowledge our sincere thanks to Prof. E.Manoutsoglou for his outstanding efforts on editorial handling and two anonymous reviewers for their suggestions. The research project was funded for I.B. and is implemented within the framework of the Action «Supporting Postdoctoral Researchers») of the Operational Program "Education and Lifelong Learning" (Action's Beneficiary: General Secretariat for Research and Technology), and is co-financed by the European Social Fund (ESF) and the Greek State.

\section{References}

Brown G.M., Pinsent R.H. and Coisy P. 1980. The petrology of spinel-peridotite xenoliths from the Massif Central, France, Am. J. Sci., 280-A, 471-498.

Coltorti M., Bonadiman C., Hinton R.W., Siena F. and Upton B.G.J. 1999. Carbonatite metasomatism of the oceanic upper mantle: evidence from clinopyroxenes and glasses in ultramafic xenoliths of Grande Comore, Indian Ocean, J. Petrol., 40, 133-165.

Coltorti M., Beccaluva L., Bonadiman C., Salvini L. and Siena F. 2000. Glasses in mantle xenoliths as geochemical indicators of metasomatic agents, EPSL, 183, 303-320.

Dawson J.B.and Smith J.V. 1982. Upper-mantle amphiboles: a review, Min. Mag., 45, 35-46.

Farmer G.L., Glazner A.F., Wilshire H.G., Wooden J.L., Pickthom W.J .and Katz M. 1995. Origin of late Cenozoic basalts at the Cima volcanic field, Mojave Desert, California, J. Geophys. Res., 100, 8399-8415.

Francis D. 1991. Some implications of xenolith glasses for the mantle sources of alkaline mafic magmas, Con. Min. Pet., 108, 175-180.

Friel J.J., Harker R.I. and Ulmer G. 1977. Armalcolite stability as a function of pressure and oxygen fugacity, Geochim. Cosm. Acta, 41, 403-410.

Gamble J.A. and Kyle P.R. 1987. The origins of glass and amphibole in spinel-wehrlite xenoliths from Foster Crater, McMurdo Volcanic Group, Antarctica, J. Petrol., 28, 755-779. 
Grègoire M., Lorand J.P., O`Reilly S.Y. and Cottin J.Y. 2000. Armalcolite-bearing, Ti-rich metasomatic assemblages in harzburgitic xenoliths from the Kerguelen Islands: Implications for the oceanic mantle budget of high-field strength elements, Geochim. Cosm. Acta, 64, 673694.

Harvey J., Yoshikawa M., Hammond S.J. and Burton K.W. 2012. Deciphering the trace element characteristics in Kilbourne Hole peridotite xenoliths: Melt-rock interaction and metasomatism beneath the Rio Grande Rift, SW USA, J. Petrol., doi: 10.1093/petrology/egs030.

Irving A.J. 1980. Petrology and Geochemistry of Composite Ultramafic Xenoliths in Alkalic Basalts and Implications for Magmatic Processes within the Mantle, Am. J. Sci., 280, 389426.

Lindsley D.H., Kesson S.E., Hartzman M.J.and Cushman M.K. 1974. The stability of armalcolite: Experimental studies in the system MgO-Fe-Ti-O, Proc. 5th Lunar Conf. (supplement 5, Geochim. Cosm. Acta), 1, 521-534.

Mason B. 1968. Kaersutite from San Carlos, Arizona, with comments on the paragenesis of this mineral, Min. Mag., 36, 997-1002.

Medvedev A.Ya. 1996. Synthetic armalcolite and pseudobrookite, Min. Mag., 60, 347-353.

Mercier J-C.C. and Nicolas A. 1975. Textures and fabrics of upper-mantle peridotites as illustrated by xenoliths from basalts, J. Petrol., 16, 454-487.

Nealey L.D. and Sheridan M.F. 1989. Post-Laramide volcanic rocks of Arizona and northern Sonora, Mexico, and their inclusions, in Jenney, J.P., Reynolds, S.J., (eds). Geologic Evolution of Arizona: Tuscon, Arizona Geological Society Digest, 17, 609-647.

Reynolds S.J. 1988. Geologic map of Arizona: Arizona Geological Survey Map 26, scale $1: 1.000 .000$

Schulze D.J., Helmstaedt H. and Cassie R.M. 1978. Pyroxene-ilmenite intergrowths in garnet pyroxenite xenoliths from a New York kimberlite and Arizona latites, Am. Min., 63, 258265.

Wilshire H.G., Nielson Pike J.E., Meyer C.E.and Schwarzman E.C. 1980. Amphibole-rich veins in Lherzolite xenoliths, Dish Hill and Deadman Lake, California, Am. J. Sci., 280-A, 576-593.

Wilshire H.G., McGuire A.V., Noller J.S.and Turrin B.D. 1991. Petrology of Lower Crustal and Upper Mantle Xenoliths from the Cima Volcanic Field, California, J. Petrol., 32(1), 169200. 